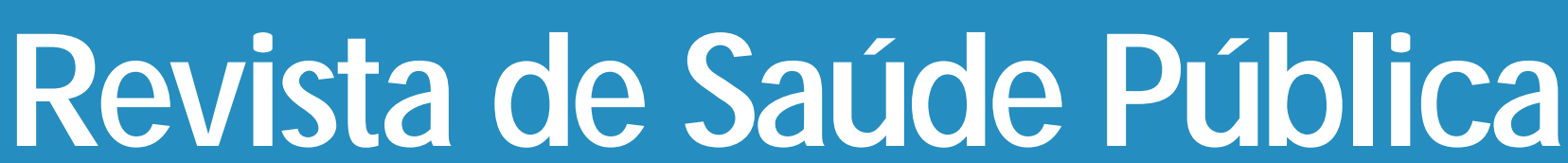

$\begin{array}{lllllll}J & 0 & U & R & N & A & L\end{array}$

0 F

P U

B L I C

H E A L T H

\title{
Epidemiological aspects of centipede (Scolopendromorphae: Chilopoda) bites registered in G reater S. Paulo, SP, Brazil*
}

Aspectos epidemiológicos de acidentes de lacraias (Scolopendromorphae: Chilopoda) em região urbana de São Paulo, Brasil

Irene Knysak, Rosana Martins and Carlos R. Bertim

Laboratório de Artrópodes do Instituto Butantan. São Paulo, SP - Brasil

KNYSAK Irene, Rosana Martins and Carlos R. Bertim Epidemiological aspects of centipede (Scolopendromorphae: Chilopoda) bites registered in Greater S. Paulo, SP, Brazil* Rev. Saúde Pública, 32 (6): 514-18, 1998

(c) Copyright Faculdade de Saúde Pública da USP. Proibida a reprodução mesmo que parcial sem a devida autorização do Editor Científico. Proibida a utilização de matérias para fins comerciais. All rights reserved. 


\title{
Epidemiological aspects of centipede (Scolopendromorphae: Chilopoda) bites registered in G reater S. Paulo, SP, Brazil*
}

\author{
Aspectos epidemiológicos de acidentes de lacraias \\ (Scolopendromorphae: Chilopoda) em região urbana \\ de São Paulo, Brasil
}

\author{
Irene Knysak, Rosana Martins and Carlos R. Bertim \\ Laboratório de Artrópodes do Instituto Butantan. São Paulo, SP - Brasil
}

\begin{abstract}
Introduction

The lack of basic knowledge on venomous arthropods and the benignity of the clinical manifestations contribute to the centipede bite victims' not being taken to a treatment reference center, leading to underestimation of the number of cases and minimizing the possibility of a broader epidemiological view. An inventory of the centipede bite occurrences in Greater S. Paulo, Brazil, and the therapeutic methods employed, by the main Brazilian medical center for the notification of poisoning by venomous animals, is presented.
\end{abstract}

Method

All patient cards of the period 1980-1989 have been checked as to place, month and time of occurrence; sex, age, affected part of the body, signs and symptoms have been observed, as well as the therapeutic methods employed. The centipedes that caused the accidents were identified at the Arthropods Laboratory.

Results It was registered 216 accidents, with a $69 \%$ predominance of the Greater S. Paulo and in only $63 \%$ of the cases (136) was the agent brought in by the victim for identification. The genera most frequently represented were Cryptops (58\%), Otostigmus (33\%) and Scolopendra (4\%). Of the 136 cases, $87 \%$ showed erythema, edema, hemorrhage, burns, cephalalgia, and intense pain. There was a predominance of accidents in the warm rainy season, in the morning and for females between 21 and 60 years of age. Hands and feet were the parts of the body most affected. The benign evolution of the clinical picture (54\%) made therapeutical treatment unnecessary. Only the victims of Scolopendra and Otostigmus (46\%) were medicated with anesthetics (51\%), analgesics $(25 \%)$, antihistamines and cortisone (24\%).

Conclusion The reproductive period of the centipedes, associated with their sinanthropic habits, contributes to the greater incidence of accidents in urban areas in the warm rainy season. Only patients bitten by Scolopendra and Otostigmus require therapeutical treatment.

Arthropod venoms. Bites and stings, therapy.

*Resumo apresentado no XV Congresso Brasileiro de Parasitologia, Salvador, BA, 1997.

Correspondence to: Irene Knysak - Av. Vital Brasil, 1500 - 05503-900 São Paulo, SP - Brasil. E-mail: crbertim@ usp.br

The publication of this article was supported by FAPESP (Process n. 97/09815-2).

Submitted on 17.3.1998. Approved on 26.6.1998. 


\begin{abstract}
Resumo
Introdução

A falta de conhecimentos básicos e a benignidade clínica contribuem para que o acidentado por lacraia não seja encaminhado a um centro de referência para tratamento. Assim, realizou-se estudo para inventariar os acidentes por lacraias na Grande São Paulo, Brasil, e apresentar a terapêutica utilizada.

Método Entre 1980 e 1989 investigaram-se os prontuários médicos quanto ao local, mês e horário dos acidentes; sexo, idade e região do corpo atingida, sinais, sintomas e terapêutica.

Resultados

Dos 216 acidentes, 69\% ocorreram na Grande São Paulo e, em 63\%, o agente causal foi identificado. Os gêneros Cryptops, Otostigmus e Scolopendra foram os mais representativos, apresentando em $87 \%$ dos casos sintomatologia evidente. Os acidentes predominaram na estação chuvosa quente, período matutino, no sexo feminino entre 21 e 60 anos nas extremidades das mãos e pés. Somente os picados por Scolopendra e Otostigmus, receberam tratamento terapêutico.

Conclusão O período de reprodução na estação chuvosa-quente, associado ao sinantropismo, favorece o aumento dos acidentes em áreas urbanas. Os acidentados por Scolopendra e Otostigmus requerem tratamento terapêtico.
\end{abstract}

Venenos de artrópodes. Mordeduras e picadas, terapia.

\section{INTRODUCTION}

The Scolopendra, whose venom is potentially dangerous for humans, has been the most commonly studied genus of the Scolopendromorphae (Bücherl2,4, 1939; 1971; Minelli' ${ }^{9}$, 1978; Jangi ${ }^{7}$, 1984). For other genera, studies on cases and poisoning are rare. According to Bücherl $^{3}$ (1946), accidents in Brazil are mainly caused by centipedes of the Cryptops, Otostigmus and Scolopendra genera.

Nocturnal, they prefer dark, moist places, taking shelter under stones, leaves and in underground galleries, feeding on other arthropods and small rodents (Jangi ${ }^{7}, 1984$ ). In urban areas, they are well adapted around and inside dwellings, where the variety of hideouts and abundance of food favor the occurrence of accidents involving human.

The Vital Brazil Hospital of the Butantan Institute (HVB-IB) is considered the main Brazilian medical center for notification of cases of poisoning by venomous animals. Of the HVB-IB's 3,000 annual cases, $5 \%$ are caused by centipedes. These arthropods are taken to the Arthropods Laboratory for identification.

Due to the scarcity of information on accidents involving centipedes in Brazil, a retrospective study of the 1980-1989 period on epidemiological and clinical aspects, as well as the treatment given at the HVB-IB for the accidents which occurred in the urban area of Greater S. Paulo area, is presented.

\section{METHOD}

The HVB-IB's file-cards for 216 centipede-bitten patients of the period from 1980 to 1989 have been analyzed.

Data have been gathered from each patient card, regarding the month, time and place at which the accident occurred in the Greater S. Paulo area, number of accidents according to the parts of the body commonly affected, signs and symptoms seen after the bite and therapeutical treatment

The centipedes brought by the victims were identified at the Arthropods Laboratory of the Butantan Institute.

The chi-square test was applied for the analysis of the significance of the data obtained, according to Glass \& Stantley $^{6}(1980)$.

\section{RESU LTS}

A $69 \%$ predominance of accidents in the Greater S. Paulo was shown by the analysis of the 216 medical patient cards.

The causing agent in 136 cases (63\%) was identified as belonging to Cryptops $(\mathrm{n}=79)$, Otostigmus $(\mathrm{n}=45)$, Scolopendra $(\mathrm{n}=5)$ and other $(n=7)$ Scolopendromorphae genera. In $37 \%$ of the cases, the centipedes could not be identified due to their poor state of preservation or to the victim's not bringing the insect in.

The number of accidents which occurred during the warm rainy season (October to March) and dry cold one (April to September) can be found in Table 1. 
Table 1 - Annual distribution of centipede bites in Greater S. Paulo 1980 - 1989 by season.

\begin{tabular}{cccc}
\hline & \multicolumn{3}{c}{ Season } \\
\cline { 2 - 4 } Year & Warm rainy & Dry cold & Total \\
\hline 1980 & 12 & 5 & 17 \\
1981 & 20 & 6 & 26 \\
1982 & 18 & 12 & 30 \\
1983 & 13 & 10 & 23 \\
1984 & 13 & 9 & 22 \\
1985 & 11 & 4 & 15 \\
1986 & 20 & 9 & 29 \\
1987 & 12 & 7 & 19 \\
1988 & 10 & 6 & 16 \\
1989 & 12 & 7 & 19 \\
\hline Total & 141 & 75 & 216 \\
\hline
\end{tabular}

The number and percentage of cases, by age and sex, are given in Table 2 .

The parts of the body commonly affected, according to the centipede genus, as well as the number and percentage of occurrences by time at which accident occurred are given in Tables 3 and 4 respectively.

The diagnosis of evident symptoms was made for 118 of the 216 victims and the most frequent clinical manifestations were erythema, edema, discreet local hemorrhage, burns, cephalalgia and intense pain (Table 5).

\section{DISCUSSIO N}

It is probable that the number of centipede accidents in the period studied presente a low percentage due to the lack of medical knowledge on human poisoning caused by these animals. The medical community's not sending the victims to a reference center for treatment results in their underregistration. The benignity of the clinical manifestations seems to contribute to the undernotification of the accidents, as the victim does not always seek medical assistance.

All the cases registered for Greater S. Paulo, occurred in urban areas, and reveal these venomous animals' sinanthropic and domestic habits.

Bücherl $^{2}$ (1939) considered the impossibility of the occurrence of accidents with small sized centipedes. According to Minelli ${ }^{9}$ (1978) and Jangi ${ }^{7}$ (1984), and in conformity with Bücherl ${ }^{2}$ (1939), small

Table 4 - N umber of cases and \% of centipede bites in Greater S. Paulo 1980 - 1989, by time of occurrence.

\begin{tabular}{lcc}
\hline Time & No. of cases & $\%$ \\
\hline $0-6 \mathrm{~h}$ & 28 & 12.9 \\
$6-12 \mathrm{~h}$ & 81 & 37.6 \\
$12-18 \mathrm{~h}$ & 47 & 21.7 \\
$18-24 \mathrm{~h}$ & 60 & 27.8 \\
\hline Total & 216 & 100.0 \\
\hline
\end{tabular}

Table 2 - N umber and percentage of centipede bites in G reater S. Paulo by age and sex, 1980 - 1989.

\begin{tabular}{|c|c|c|c|c|c|c|}
\hline \multirow{3}{*}{$\begin{array}{l}\text { Age } \\
\text { (years) }\end{array}$} & \multicolumn{4}{|c|}{ Sex } & & \\
\hline & \multicolumn{2}{|c|}{ Females } & \multicolumn{2}{|c|}{ Males } & \multicolumn{2}{|c|}{ Total } \\
\hline & $\bar{N}$ & $\%$ & $\mathrm{~N}$ & $\%$ & $\bar{N}$ & $\%$ \\
\hline $0-10$ & 9 & (6.4) & 26 & $(34.2)$ & 35 & $(16.2)$ \\
\hline $11-20$ & 10 & $(7.1)$ & 11 & (14.5) & 21 & (9.7) \\
\hline $21-30$ & 32 & $(22.9)$ & 10 & (13.2) & 42 & (19.4) \\
\hline $31-40$ & 38 & $(27.2)$ & 9 & (11.8) & 47 & $(21.8)$ \\
\hline $41-50$ & 31 & $(22.1)$ & 9 & (11.8) & 40 & (18.5) \\
\hline $51-60$ & 11 & $(7.9)$ & 8 & (10.6) & 19 & (8.8) \\
\hline over 60 & 9 & (6.4) & 3 & (3.9) & 12 & (5.6) \\
\hline Total & 140 & $(100.0)$ & 76 & $(100.0)$ & 216 & $(100.0)$ \\
\hline
\end{tabular}

Table 3 - Parts of the body bitten by centipedes identified at the Arthropod Laboratory.

\begin{tabular}{lrrrrrrr}
\hline \multirow{2}{*}{$\begin{array}{l}\text { Part of the } \\
\text { body }\end{array}$} & Cryptops & Otostigmus & Scolopendra & Scolopocryptops & Rhysida & O ther & Total \\
\cline { 2 - 7 } & $33(41.8)$ & $18(40.0)$ & $2(40.0)$ & $3(60.0)$ & - & $1(50.0)$ & $57(41.6)$ \\
Hands & $1(1.3)$ & $1(2.2)$ & - & - & - & - & $2(1.5)$ \\
Arms & $36(45.5)$ & $18(40.0)$ & $3(60.0)$ & $1(20.0)$ & $1(100.0)$ & - & $59(43.1)$ \\
Feet & $3(3.8)$ & $2(4.4)$ & - & - & - & - & $5(3.6)$ \\
Legs & $2(2.5)$ & $1(2.2)$ & - & $1(20.0)$ & - & - & $4(2.9)$ \\
Thorax/Back & $4(5.1)$ & $5(11.1)$ & - & - & - & $1(50.0)$ & $10(7.3)$ \\
Others & $79(100.0)$ & $45(100.0)$ & $5(100.0)$ & $5(100.0)$ & $1(100.0)$ & $1(100.0)$ & $137(100.0)$ \\
\hline Total & & & & & & &
\end{tabular}


Table 5 - M ain symptoms presenting after centipede bite, by genus.

\begin{tabular}{|c|c|c|c|c|c|}
\hline \multirow{2}{*}{ Symptoms } & \multicolumn{5}{|c|}{ Genus } \\
\hline & Cryptops & O tostigmus & Scolopendra & O ther & Total \\
\hline \multirow[t]{2}{*}{ Erythema } & 20 & 26 & 2 & 5 & 53 \\
\hline & $37.7 \%$ & $49.1 \%$ & $3.8 \%$ & $9.4 \%$ & $100.0 \%$ \\
\hline \multirow[t]{2}{*}{ Edema } & 13 & 21 & 4 & - & 38 \\
\hline & $34.2 \%$ & $55.3 \%$ & $10.5 \%$ & - & $100.0 \%$ \\
\hline \multirow[t]{2}{*}{ Hemorrhage } & 6 & - & - & 1 & 7 \\
\hline & $85.7 \%$ & - & - & $14.3 \%$ & $100.0 \%$ \\
\hline \multirow[t]{2}{*}{ Burns } & 3 & 2 & - & 1 & 6 \\
\hline & $50.0 \%$ & $33.3 \%$ & - & $16.7 \%$ & $100.0 \%$ \\
\hline \multirow[t]{2}{*}{ Cephalalgia } & 1 & 1 & - & 1 & 3 \\
\hline & $33.3 \%$ & $33.3 \%$ & - & $33.4 \%$ & $100.0 \%$ \\
\hline \multirow[t]{2}{*}{ Pain } & 2 & 9 & - & - & 11 \\
\hline & $18.2 \%$ & $81.8 \%$ & - & - & $100.0 \%$ \\
\hline \multirow[t]{2}{*}{ Total } & 45 & 59 & 6 & 8 & 118 \\
\hline & $38.1 \%$ & $50.0 \%$ & $5.1 \%$ & $6.8 \%$ & $100.0 \%$ \\
\hline
\end{tabular}

sized specimens find it difficult to insert their mandibles into the human skin. Nevertheless, this study has shown contrary results as some of the accidents occurred with the Cryptops and Otostigmus genera, both under $5 \mathrm{~cm}$ in lenght. The annual distribution of centipede bites in the Greater S.Paulo area, between 1980 and 1989, showed the greatest frequencies for Cryptops (57.7\%) and Otostigmus (33.6\%). The chi-square test showed significance $\left(\mathrm{X}^{2}=109.2 ; \mathrm{p}=0.001\right)$ for both genera.

As for seasonality, Duboscq 1894, 1898 (apud Minelli', 1978), in his study on Scolopendra cingulata, observed differentiated reactions in the victims' symptoms, showing that during the European winter the clinical aspects are milder than in the summer. This was not evident, in the present study, though an increase in the number of accidents between December and January has been registered, perhaps related to the greater availability of food and to the centipedes' reproductive period that occur in the warm rainy season.

There was a threefold dominance of females between 21 and 60 years of age $\left(X^{2}=35.25 ; p=0.001\right)$ among the victims, these accidents being related to household activities, according to the patient cards. Between 0 and 10 years of age, males have been more frequently bitten. The more commonly affected parts of the body are the extremities of the upper and lower limbs, although no significant difference in percentages for Otostigmus and Cryptops genera have been found $\left(\mathrm{X}^{2}=1.87 ; \mathrm{p}=0.866\right)$ in terms of the affected part of the body.

The frequency of centipede accidents by time of occurrence is significant $\left(X^{2}=27.59 ; p=0.001\right)$, indicating greater frequency in the morning, between 6 and 12 o'clock, when human activity starts.

The main symptoms shown after the bite were erythema and edema. The proportions by symptoms analyzed for the Otostigmus and Cryptops genera are significant $\left(X^{2}=11.6 ; p=0.040\right)$, these proportions differing according to genus. Nevertheless, this result must be taken as tentative, due to the number of empty table cells, with expected frequencies <5 (low frequencies).

For 63 patients, HVB-IB's therapeutic methods were: anesthetic $(51 \%)$, analgesic (25\%), antihistamine and cortisone (24\%). Local infection is not uncommon as a complication (Blay ${ }^{1}$, 1955). According to Haneveld ${ }^{5}$ (1957), there is the possibility of secondary contamination by the bacterial antigen Spirullum minus at the moment of the bite, justifying the cortisone treatment. When the anesthetic block is necessary, subcutaneous infiltration of lidocaine $2 \%$, or derivatives, without vasoconstrictor at the place of the bite or at the neural branch is recommended (Knysak et al. $\left.{ }^{8}, 1994\right)$. Only patients bitten by Scolopendra and Otostigmus have received such treatment.

New analyses of epidemiological aspects of centipedes are becoming available for comparison with the results obtained in this study. Accurate identification of centipedes, as well as of the places of the occurrence of accidents that should help in the clarification of other aspects have been being made since 1990, mainly related to symptomatology and therapeutic treatment. 


\section{ACKN O W LED G MENTS}

To Dr. Eunice A. Galati of the Epidemiology Department, "Faculdade de Saúde Pública da Universidade de São Paulo", for the valuable suggestions;

\section{REFEREN CES}

1. BLAY, E.R. Treatment of centipede bites. Br. Med. J., 2: $1619,1955$.

2. BÜCHERL, W. Quilópodos do Brasil. Mem. Inst. Butantan., 23: 1-320, 1939 .

3. BÜCHERL, W. Ação do veneno dos escolopendromorfos do Brasil sobre alguns animais de laboratório. Mem. Inst. Butantan., 19: $181-98,1946$.

4. BÜCHERL. W. Venomous chilopods or centipedes. In: Bücherl, W. \& Buckley, E.E. Venomous animals and their venoms. New York, Academic Press, 1971. p. 169 - 96.

5. HANEVELD, G.T. Centipides bites. Br.Med.J., 2: 592, 1957.
Dr. João Luiz Costa Cardoso of the Hospital Vital Brazil, Instituto Butantan, for permission to examine the patient cards, and Darci M.B.Battesti of the Arthropods Laboratory, Instituto Butantan, for her valuable suggestions and encouragement.

6. GLASS, G.V. \& STANLEY, J.C. Metodos estatisticos aplicados a las ciencias sociales. Madrid, Editorial Prentice/Hall International, 1980.

7. JANGI, B. S. Centipede venoms and poisoning. In:Tu,A.T. Handbook of natural toxins: insect poisons, allergens, and other invertebrate venoms. New York, Marcel Dekker, 1984. p. 333-68.

8. KNYSAK, I.; MARTINS, R.; BERTIM, C. R.; WEN, F.H. Lacraias de importância médica no Estado de São Paulo: biologia e aspectos epidemiológicos. São Paulo. Centro de Vigilância Epidemiológica. Secretaria de Estado da Saúde, 1994. [Documento Técnico].

9. MINELLI, A. Secretions of centipedes. In: Bettini, S. Arthropod venoms: handbook of experimental pharmacology. Heidelberg, Springer-Verlag, 1978. p. 73 - 85. 